\title{
A Register-Based Perspective to Suprasegmentals in ELT
}

\section{El enfoque de registro lingüístico en la enseñanza de aspectos suprasegmentales del inglés}

\author{
Henry Sevilla Morales ${ }^{1}$ \\ Lindsay Chaves Fernández ${ }^{2}$
}

Fecha de recepción: 17-01-2020

Fecha de aceptación: 26-o6-2020

\begin{abstract}
Resumen
La presente reseña sistematiza las experiencias pedagógicas de dos docentes de inglés que imparten cursos de aspectos suprasegmentales o prosódicos utilizando un enfoque de registro lingüístico. Dicho enfoque propone que los elementos prosódicos deben abordarse desde una perspectiva comunicativa, donde los actos del habla se ajusten a las situaciones comunicativas específicas, con base en el nivel de formalidad requerido (casual, informal, formal o fijo). En su mayoría, la propuesta deriva de la experiencia empírica de los autores impartiendo cursos de pronunciación en la Universidad Nacional, Costa Rica (UNA) y la Universidad de Costa Rica (UCR) durante los últimos cuatro años.
\end{abstract}

Palabras clave: registro linguístico, discurso interconectado, acento, ritmo, entonación.

\begin{abstract}
The current paper is a systematization of EFL experiences around the teaching of suprasegmentals courses from a register-based perspective. Simply put, the proposal is based on the notion that prosodic elements must be taught from a communicative perspective, where speech acts are adjusted to specific communicative situations considering the formality level required (casual, informal, formal, or fixed). To a large degree, the approach derives from the authors' empirical evidence gained while teaching suprasegmentals at Universidad Nacional, Costa Rica (UNA) and Universidad de Costa Rica (UCR) over the course of four years.
\end{abstract}

Keywords: language register, connected speech, stress, rhythm, intonation.

\footnotetext{
1 Máster en Segundas Lenguas y Culturas. Universidad Nacional, Escuela de Literatura y Ciencias del Lenguaje; Universidad de Costa Rica, Sede de Occidente, Costa Rica. Correo electrónico: henry.sevilla.morales@una.ac.cr

2 Máster en Segundas Lenguas y Culturas. Universidad Nacional, Escuela de Literatura y Ciencias del Lenguaje, Costa Rica. Correo electrónico: lindsay.chaves.fernandez@una.ac.cr
} 


\section{Introducción}

English pronunciation (EP), a central sub-skill across virtually any English Language Teaching (ELT) program, continues to gain unprecedented attention both in theory and in practice (e.g., Bakla, 2018; Cerezo, Calderón, \& Romero, 2019; Gamboa, Chaves, Vásquez, \& Gapper, 2019; Kralova, Skorvagova, Tirpakova, \& Markechova, 2017; Sevilla, 2019; and Zoghbor, 2018). A major challenge appears, however, in classroom application, since EP instruction often involves making sensitive decisions around the type and amount of input, the choice of modeling accents, responding to the program's goals, assuring curricular flexibility, fostering pedagogical empowerment, and the not-so-uncommon lack of methodological expertise on the part of teachers and program designers at large. Particularly when addressing suprasegmentals (i.e. word and sentence stress, rhythm, intonation, connected speech, etc.), difficulties arise if we teach EP across different language registers (levels of formality) to suit interlocutors' communicative purpose and contexts (see Breitkreutz, Derwing, and Rossiter, 2001; Baker, 2011).

Such difficulties intensify because the acquisition of suprasegmentals involves an overwhelming number of technical processes and breaks away from the discretepoint approach commonly used in segmental (vowels and consonants) courses. Within this complexity, students must learn to shift from slow, careful pronunciation to a number of adjustments and phonetic processes in connected speech such as elision, assimilation, vowel neutralization, substitution, allophonic variation, aphesis, epenthesis, cluster simplification, blending, palatalization, pausing, phrasing, and many more.

In an attempt to offer partial solutions to this issue, this systematization paper discusses pedagogical practices we have used to meet the challenges described above. Such practices have consolidated from several years of experience and research-based decisions we have made as EP instructors at UNA and UCR. While our proposal does not seek generalizations of any sort, our work is significant at two levels: (1) For theory, it builds a working framework for the EP instruction in EFL and
ESL contexts, which encourages the running of studies to test its degrees of effectiveness in other settings. (2) For practice, it provides hands-on resources for immediate application in the ELT classroom. It is our hope to open a space for dialogue and an avenue for further research around this subfield of study.

In order to narrow down the scope of our paper, a theoretical grounding section is offered in the lines ahead, and has been arranged into four subsections: (1) an introduction to the prosody pyramid, where Gilbert's (2008) principles for English prosody are outlined, including aspects such as thought groups, focus word, stressed syllable, peak vowel, and pitch drops to signal thought completion; (2) the basics of stress, intonation, and rhythm, where key terminology is defined and an inventory of intonation patterns is be discussed; (3) adjustments in connected speech, where suprasegmental features such as blending and word reductions, linking, pausing and phrasing, assimilation, cluster simplification, omission, and others, are exemplified in context; and (4) register shift, where examples of pronunciation changes according to specific levels of reading and spoken formality are addressed. The paper also features potential contexts of implementation and samples key teaching resources for immediate usage. Based on our systematization, we lay out a few conclusions, identify some limitations, and propose future directions for empirical research.

\section{Theoretical Grounding}

Because this is a systematization of teaching experiences in EFL and as such it does not seek to test previously drawn hypotheses, this section does not offer a review of previous studies. While seminal work on pronunciation was naturally considered as baseline for the paper (e.g., Murphy, 2017; Jarosz, 2019; and Derwing and Munro, 2015), below we only discuss some theoretical underpinnings that guided the implementation of the activities (for expansion, see Creswell, 2014, p. 29).

To better understand the conceptual framework below, some key terms need to be defined. The first one is segmentals, which refers to the acquisition of separate speech units; i.e., vowels and consonants (Saito, n.d., 
p. 2). The second is suprasegmentals, or the study of rhythm, stress, pitch, intonation, and other phonological processes in connected speech. We call it suprasegmentals because it is the study of speech beyond individual (supra) segments (ibid.). Connected speech stands for the third element. Also called connected discourse, reduced speech, or Sandhi variation, connected speech refers to spoken language which exhibits the natural elements of a language system, as in casual conversations (British Council, n.d.). In English, connected speech means articulating discourse that includes linking, elision (also called deletion), assimilation, aphesis, epenthesis, and many others (Celce-Murcia, Brinton, \& Goodwin, 1996).

That said, the lines ahead address the first four theoretical considerations upon which our discussion is based. The last part (sample activities) will be developed in the methodology section.

\subsection{The Prosody Pyramid}

According to Gilbert (2008), the prosody of English can be compared to a pyramid. Such pyramid has at the base a thought group, and then a focus word, which in turn has a stressed syllable, which also contains a peak vowel (p. 10). Thought groups, according to the author, are phrases or chunks of spoken language that carry a thought; they can be a short sentence, a clause, and even a word such as wow! ouch! or hey! The focus word is the most important word in a thought group, and its emphasis is usually determined by the context and the speakers' intention. As a general rule, focus words in a thought group are usually content words (i.e., nouns, adjectives, interjections, verbs, adverbs, and other major words). On the other hand, structure words (or function words) are not usually the focus word in a thought group and they include pronouns, prepositions, articles, auxiliary verbs, etc. (ibid.)

The stressed syllable is that which receives the primary stress in multi-syllable words. In the words of Gilbert, "every English multi-syllabic word has a syllable that receives the main stress" and should therefore be pronounced with greater prominence (id., p. 14). In the focus word, this author adds, stressed syllables get special attention because they represent the peak of information in the thought group. Within that stressed syllable, there will always be a peak vowel, which is extra clear and extra-long for the purpose of meaning accuracy. Below is an adaptation of the prosody pyramid diagram offered by Gilbert.

Figure 1: The Prosody Pyramid

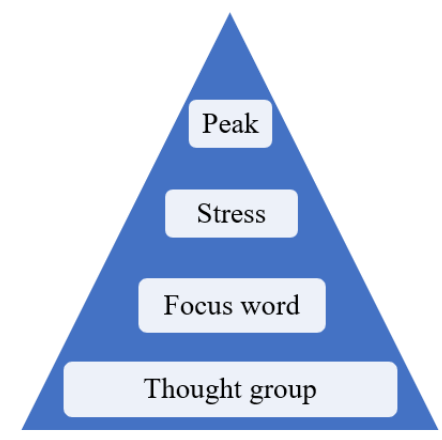

Fuente: Gilbert (2008, p. 10) ${ }^{3}$

Since spoken English (or any other spoken language) holds no punctuation, "listeners must rely entirely on prosodic markers in order to know which words are grouped together" (id., p. 11). For instance: We arrived lAte, so we couldn't see the mOvie. They must also be attentive to pitch drops which signal the end of thought groups. While there would seem to be rules for when a thought group ends, EFL students and teachers are encouraged to develop phonological awareness on this not only in everyday conversational language, but also in other language registers such as radio talk, academic conferences, and specialized fields to figure out the pitch patterns of each context. Gilbert (2008) provides the following advice on how to interpret pitch drops:

In general, a pitch drop means "the end," and there is a relationship between the degree of finality and the size of the drop. For instance, a slight drop in intonation typically marks the end of a thought group within a sentence; a bigger drop marks the end of a sentence or an entire

3 Gilbert, J. B. (2008). Chapter 2: The Prosody Pyramid. In Teaching Pronunciation: Using the Prosody Pyramid (pp. 10-20). New York: Cambridge University Press. 
comment; a major drop indicates, "I have finished my remarks, and it is now your turn to speak." (pp. 11-12)

\subsection{Stress, Rhythm, and Intonation: The Basics}

Put simply, stress refers to the emphasis placed in syllables, words, and sentences in spoken language. Syllable stress refers to the primary, secondary or tertiary stress received by each syllable in multisyllabic words, which also implies that the syllables are "said louder, [...] on a higher pitch, and [...] held longer than the other vowel sounds in the same word" (Orion, 1997, p. 19). Word stress, along the same lines, deals with where the stress falls in words, be them base words, noun compounds, noun-verb homographs, or word compounds of several prefixes and affixes. In English, most experts agree with three levels of word stress: strong, medial, and weak (Celce-Murcia et al., 1996, p. 132). Lastly, sentence stress is understood as emphasizing and deemphasizing words across utterances to attain natural rhythm (Dale \& Poms, 2005, p. 91) or, as Celce-Murcia et al. have simplified it, as "the various stressed elements of each sentence” (id., p. 151).

The latter define rhythm as "the regular, patterned beat of stressed and unstressed syllables and pauses," which is achieved by combining effective syllable, word, and sentence stress (id., p. 152). This stress-timed nature of the English language is what determines the length of an utterance and stands and helps give intonation a more natural-sounding quality. It is this 'musical' trait what helps give sentences such as "CATS CHASE MICE", "CATS have CHASED MICE", "the CATS have CHASED the MICE" AND "the CATS have been CHASING the MICE" virtually the same duration (ibid.).

Along with rhythm, effective communication requires effective intonation; that is, the melody of language: the rises and falls used to signal various types of melodic patterns in different utterances such as statements; -wh, tag, echo and confirmation questions, commands; alternatives with or; enumerations; and a wide host of others. According to Yoshida (2014), proper intonation is vital since it helps, for example, change a statement into a question, or make a request more polite or assertive, and "make a speaker sound happy, sad, sincere, angry, confused, or defensive" (p. 123). While more than one kind of intonation has been identified by professionals on the subject, three essential typologies have been suggested by Yoshida (ibid): 1. a final fall (typical in statements, commands, -wh questions, and irony), 2. a final rise (common in yes-no questions, echo questions, and repetitions), 3. and a partial fall (common in incomplete thoughts or a sudden interruption to elaborate on one's thoughts) (pp. 129-130).

\subsection{Adjustments in Connected Speech}

Along with the stress, rhythm, and intonation elements of English pronunciation, real-life communication requires a number of other adjustments. These include, among others, blending and word reductions (putting various words together to form a single speech unit, as though everything was one word), linking (one final sound in a word to the first sound of the next word), and phrasing and pausing (dividing utterances into thought groups depending on punctuation, connectors, conjunctions, etc.), as Dale and Poms (2005, p. 99) have suggested. In addition to these processes, sounds also become more like one another depending on the conditioning environment around them; thus, spoken English undergoes three types of assimilation: progressive, regressive (or backward), and coalescent (or reciprocal) (Vásquez, 2020). In progressive assimilation, a succeeding phoneme is affected by the phoneme immediately before it, as in the case of "They wanted to come" = [ðе ' 'wantıd tə $\mathrm{k} \Lambda \mathrm{m}$ ]; in regressive assimilation, the assimilated sound is affected by the sound following it, such as in "You have to believe it" $=$ [ju hæftə bə'li:v It]. In coalescent assimilation, two neighboring sounds influence each other and give way to a whole new phoneme, often an affricate (/t $\int$ / or / $\mathrm{d} 3 /$ ) in a process called palatalization, as in "Is that your best idea?” = [ız ðætfər best aı'diə?] (see Dawood \& Atawneh, 2015).

To add to the existing intricacies of connected speech, students often need to "unlearn" the pronunciation of carefully articulated clusters such as "sts" (/sts/) or "th's" (/बs/) and simplify them to conform to the ways in which 
native speakers would pronounce them. Thus, a cluster like "sts" in "tests" becomes /s/ in a chunk of connected speech like "We take tests all weeks" = [wi: terk tes_o:1 wi:ks] (see Dauer, 1993, pp. 159-160). Lastly, some vowels and consonants can be omitted in rapid speech, such as the first /r/ in "surprise" or "February" in most varieties of General American English.

\subsection{Register Shift}

In addition to the above, actual communication always demands shifting from one degree of formality to another based on the speech acts the interlocutors engage in (be that spoken or in writing), which in the case of oral discourse calls for adjustments in the type of suprasegmental features needed for such speech acts. This swapping of formality levels is what we prosaically understand as linguistic register. In the words of Gray and Egbert (2019), register refers to "the linguistic differences" employed by language users "depending on the context of use" (p. 1). ${ }^{4}$ To attain this shift, in courses covering suprasegmentals, students should be provided with the learning opportunities to use rhythm, intonation, pitch drops, reductions, cluster simplifications, etc., to navigate different registers required for formal, casual, or informal communication. In the lines ahead, we provide a description of the contexts where we have used registerbased activities to reach this goal.

\section{Suggested Implementation Setting}

The proposal has so far worked well with college students already possessing knowledge of segmentals. It has been implemented by the two researchers of this paper since 2016 at two public universities in Costa Rica: Universidad Nacional and Universidad de Costa Rica. Student ages have ranged from 19 to 28 and have all attended classes on a regular basis in three language programs: 1. B.A. in
TESOL for young adults, 2. B.A. in TESOL for children, and 3. B.A. in English. Nonetheless, the activities can be adapted to other populations, such as bilingual high schools and elementary schools, INA ${ }^{5}$ courses, and other programs where pronunciation courses are part of the curriculum. For all cases where the proposal has worked out well, students have possessed a high level of English proficiency so that they can shift registers from context to context.

\section{Suggested Resources}

This section offers a quick inventory of activities to foster suprasegmental skills across various language registers and communicative contexts. Each resource is described in terms of learning goal(s), target register, time, resources, and procedures.

\subsection{Activity 1: "Happiness" (Short Film by Steve Cutts)}

Learning Goal: to reflect upon the elements of connected speech fluently and accurately across three levels of formality 6

Target Registers: informal, casual, and formal

Suggested Time: 60 minutes

Resources: A video projector, speakers, a laptop or a $\mathrm{PC}$, a handout with these instructions, paper and pencil

\section{Procedures:}

1. Students will watch the video "Happiness," by Steve Cutts, ${ }^{7}$ where the author depicts a world of mice who become alienated in their own pursuit of happiness. -The comparison between these mice and the human race is more than obvious.

\footnotetext{
$4 \quad$ For a full review of papers on register studies across various disciplines, see the journal Register Studies, inaugurated in 2019 by John Benjamins Publishing Company, and which by January 2020 had published three issues dedicated explicitly to the thriving subfield of language register.

5 Costa Rica’s National Learning Institute (by its initials in Spanish)

6 To do this activity, students need previous knowledge of suprasegmentals.

7 Video available at: https://www.youtube.com/watch?v=egdZQelULDk
} 
2. Once they have watched the video, they will complete the following speaking tasks about the content of the video. They will keep the communicative contexts in mind, adjusting their pronunciation register to each context.

a) An informal Conversation

Context: A cafeteria on campus. Students bump into each other and talk about the content of the video they saw and how it impacted them personally. They should be free to use contractions, reductions, emotional intonation, rising intonation to create suspense, and other elements studied.

b) A Job Interview

Context: A Call Center. The interviewer is a relaxed, casual recruiter who wants to know the interviewee's standpoint on consumerism and happiness. S/he asks the interviewee to talk about a recent video they watched on the subject. Students should feel free to use contractions and reductions here and there, rising intonation to create suspense from time to time, and other elements studied. (Then students swap roles.)

\section{c) A Verbal Essay}

Context: A colloquium at a conference: The students are given 5 minutes to share their ideas on happiness and consumerism. As typical in a verbal essay, they should include discourse markers to introduce their topic, develop three sub-topics, issue a conclusion, and invite questions from the audience. The audience will be integrated by professionals of different areas, including commerce, economy, and sociology.

3. Once the three speaking activities have been conducted, students comment on the experience of switching levels of formality for one same topic. They rate the frequency of elements of connected speech used in each task: $1=$ never, $2=$ almost never, 3 = sometimes, $4=$ almost always, and $5=$ always.

\begin{tabular}{|l|l|l|l|}
\hline $\begin{array}{l}\text { Elements of Connected } \\
\text { Speech }\end{array}$ & $\begin{array}{l}\text { Task 1 } \\
\text { (Casual- } \\
\text { Informal) }\end{array}$ & $\begin{array}{l}\text { Task 2 } \\
\text { (Casual- } \\
\text { Formal) }\end{array}$ & $\begin{array}{l}\text { Task 3 } \\
\text { (Formal- } \\
\text { Academic) }\end{array}$ \\
\hline Short pitch drops & & & \\
\hline Longer pitch drops & & & \\
\hline Extra-long pitch drops & & & \\
\hline $\begin{array}{l}\text { Rising intonation for } \\
\text { suspense }\end{array}$ & & & \\
\hline $\begin{array}{l}\text { Falling intonation to } \\
\text { signal end of thought } \\
\text { groups }\end{array}$ & & & \\
\hline $\begin{array}{l}\text { Pausing and phrasing } \\
\text { Emphasis on content } \\
\text { words }\end{array}$ & & & \\
\hline $\begin{array}{l}\text { Reduction of function } \\
\text { words }\end{array}$ & & & \\
\hline $\begin{array}{l}\text { Vowel clarity and quality } \\
\text { for emphasis }\end{array}$ & & & \\
\hline $\begin{array}{l}\text { Blending and reductions } \\
\text { assimilations, linking, etc.) }\end{array}$ & & & \\
\hline $\begin{array}{l}\text { Consonant cluster } \\
\text { simplification }\end{array}$ & & & \\
\hline Suprasegmental processes & & & \\
\hline
\end{tabular}

4. While the students work on step 3, the professor circulates, offering help and inviting students to share their feelings about the activity with him/ her. The activity can be wrapped up with a plenary session to discuss the results from 3 above.

\subsection{Activity 2: IPA Transcriptions in Various Forms of Connected Speech}

Learning Goal: to compare the elements of connected speech across three types of language registers using the IPA, diacritical marks, and some common phonetic processes such as assimilation, omission, linking, vowel neutralization, palatalization, etcetera.

Target Registers: casual, formal, and fixed

Suggested Time: two hours

Resources: internet access, a media player device (a laptop, a smartphone, etc.) paper, and pencil 


\section{Procedures:}

This activity works well as a graded out-of-class assignment. Students will compare the elements of connected speech across three types of language registers (casual, formal, and fixed) using the IPA, diacritics, and the phonetic processes already studied (assimilation, omission, linking, and neutralization, blending, etc.). Students are advised to complete this assignment either in pairs or in groups of three.

\section{Instructions:}

1. This assignment needs be hand-written.

2. Students will watch three video clips and provide a phonetic transcription using the IPA and the diacritical marks studied in class.

3. For the first video (Sheldon's Speech), transcribe from 1'22 to 2'05.

4. For the second video (Best Moments of Sheldon Lee Cooper...), transcribe from o' 40 to o' 56 .

5. For the third video (Why Socrates Hated Democracy), transcribe from o'56 to 1'23.

6. To access the videos, click on the following links:

a) https://www.youtube.com/watch?v= 2tSfSZ8zu8s (fixed language register)

b) https://www.youtube.com/watch?v= HfPtD50SXaw (casual language register)

c) https://www.youtube.com/watch?v= fLJBzhcSWTk (formal language register)

7. This assignment needs be hand-written.

\section{Suggested Assessment Criteria:}

1. Accuracy of vowel transcriptions

2. Accuracy of consonant transcriptions

3. Diacritical marks used
Aspects of connected speech represented (omissions, reductions, blending, etc.)

\section{Activity 3: Shadow Reading}

Learning Goal: to identify elements of the prosody pyramid to emulate the suprasegmental elements of an interview excerpt

Target Registers: formal to casual

Suggested Time: 40 minutes

Resources: internet access, a media player device (a laptop, a smartphone, etc.) paper, and pencil

\section{Procedures:}

Part A (Identification): Students watch two sections of the video where Fox News anchor Lauren Green interviews Reza Aslan, a scholar of religious studies, about a new book he has published. ${ }^{8}$ As students watch each section, they should pay attention to where each thought group begins and ends. Also, they are encouraged to locate the focus word and its stressed syllable and peak vowel.

Segment 1: o'26-o'46

Green: "You're a Muslim, so why did you write a book about the founder of Christianity?"

Aslan: "Well, to be clear, I am a scholar of religions with four degrees, including one in the New Testament, and fluency in biblical Greek, who has been studying the origins of Christianity for two decades," Aslan says, "who also just happens to be a Muslim."

Segment 2: 6'55-7'19

Green: Taylor Cain says, "so your book is written with clear bias and you're trying to say it's academic; that's like having a Democrat write a book about why Reagan wasn't a good Republican; it just doesn't work." What do you say about that?

Aslan: It would be like a Democrat with a Ph.D. in Reagan who has been studying his life and history for two decades writing a book about Reagan. 


\section{Part B (Shadow Reading):}

1. Now that students are familiar with the segments from above, they watch a video about the shadowing technique for pronunciation rhythm and intonation. Here they will learn about how to emulate a native speakers' rhythm, intonation, pitch, and other elements of connected speech.

2. The professor then plays the closed captions for the first 2 minutes of the video and asks students to act out the segment in pairs, trying to emulate the speakers' suprasegmental elements as they do through the captions.

3. The professor pauses the video segments at five-second intervals so students can imitate the speakers' prosody.

4. The activity concludes with a reflection session where students verbalize their strengths and weaknesses trying to implement the shadowing technique.

\section{Activity 4: Round Table}

Learning Goal: to speak formally about a topic students have previously inquired on

\section{Target Register: formal}

Suggested Time: 5 to 6 minutes (this might change depending on class time availability)

Resources: Students are allowed to research about the topic they choose using the Internet, books, magazines, or any other resources they deem necessary.

\section{Procedures:}

Prior to this activity, students must get into groups, choose a topic, divide it into sections, and be ready to perform the round table in class.

\section{Instructions:}

Before the round table:

1. The team must divide the topic into sections (depending on the number of speakers), assign a sub-topic (section) to each speaker, and agree on the order for the discussion, as well as other logistic details.

2. The team must also create an agenda to organize their ideas and order of participation. They are advised to inform about this agenda at the beginning of the round table.

During the round table:

3. One of the members will give a short overview of the topic. Then, the discussion will follow with each participant presenting their sub-topic to the rest of the team.

4. Once everyone has presented their share of the work, someone will issue a brief conclusion. The team may: (1) finish with a small recount or summary of the main points you discussed, or (2) use a general concluding statement that is memorable and serves to both signal the end of your speech and close your presentation.

Optional: To assess ability to switch to a more casual register, students might be required to perform an informal conversation between friends at a public place (a cafeteria, for instance). They should be reminded that casual speech uses fewer pauses, employs more connected speech, can be more emotional, might use higher pitch, and lends itself for shorter interventions and frequent interruptions.

\section{Suggested Assessment Criteria:}

- Speech fluency

- Accuracy of vowel sounds

- Accuracy of consonant sounds 
- Intonation and rhythm

- Different aspects of connected speech (omissions, substitutions, reductions, blending, etc.).

\section{Conclusions}

Insofar as our experience is concerned, this proposal has proven effective for the teaching of registerbased suprasegmentals in the contexts where it has been implemented (UCR and UNA). With a good dose of caution and the necessary adjustments to suit contextual variables, these insights can be transferred to larger populations across Costa Rica and elsewhere. Nonetheless, there are a number of limitations which need to be kept in mind. First of all, a good deal of knowledge on suprasegmentals and language registers is needed, along with expertise on scaffolded language education to lead students from the most basic to the most intricate elements of suprasegmentals within this methodology. Secondly, students must possess a high level of English proficiency before they are required to shift across levels of formality. In doing so, instructors might easily risk accuracy at the expense of fluency, misleading students into the false belief that, as long as they are able to communicate fluently, they should not worry a lot about speech accuracy. The third limitation is what Ian Tudor (2001) has called "conflicting rationalities." In other words, chances are very high that the students, the professors, the curriculum developers, and society hold different reasons for learning English. This, in turn, causes conflicts between what teachers believe is best for students, what students believe they need to learn, what curriculum developers and policy makers conceive as quality education, and what society ultimately expects for new professionals to know about the target language. In addition to that, since we are dealing with a relatively new topic in language education, ELT programs and curricular authorities should consider proper teacher training before implementing this or similar approaches.

That having been acknowledged, our paper has outlined some possibilities for teaching pronunciation to achieve suprasegmentals competence in different communicative contexts. Further efforts should be addressed to testing, empirically, the impact of such approach in students, instructors, and the school curriculum. For now, some modest bases have been built to allow for replication of this pedagogical experience and open an avenue of reflection, best practices, and further research around this subject area.

\section{References}

Baker, A. (2011). Pronunciation Pedagogy: Second Language Teacher Cognition and Practice. ScholarWorks @ Georgia State University.http:// scholarworks.gsu.edu/alesl_diss/16

Bakla, A. (2018). Learner-generated materials in a flipped pronunciation class: A sequential explanatory mixed-methods study, Computers \& Education, 125, 14-38. https://doi.org/10.1016/j. compedu.2018.05.017

Breitkreutz, J., Derwing, T., \& Rossiter, M. (2001). Pronunciation Teaching Practices in Canada. TESL Canada Journal, 19(1), 51-61. https://doi.org/10.18806/tesl.v19i1.919

British Council. (n.d.). Connected. Speech. https://www. teachingenglish.org.uk/article/connected-speech

Celce-Murcia, M., Brinton, D., Goodwin, J. (1996). Teaching Pronunciation: A Reference for Teachers of English to Speakers of Other Languages. Cambridge: Cambridge University Press.

Cerezo, R., Calderón, V. \& Romero, C. (2019). A holographic mobile-based application for practicing pronunciation of basic English vocabulary for Spanish speaking children, International Journal of Human-Computer Studies, 124, 13-25. https:// doi.org/10.1016/j.ijhcs.2018.11.0o9

Creswell, J. W. (2007). Qualitative Inquiry and Research Design: Choosing Among Five Approaches (2nd edition). Sage Publications, Inc. 
Dale, P., \& Poms, L. (2005). English Pronunciation Made Simple. White Plains, NY: Longman.

Dauer, R. A. (1993). Accurate English: A Complete Course in Pronunciation. Englewood Cliffs: Prentice Hall Regents.

Dawood, A., \& Atawneh, A. (2015). Assimilation of consonants in English and assimilation of the definite article in Arabic. American Research Journal of English and Literature, 1(4). 9-15.

Derwing, T. M., \& Munro, M. J. (2015). Pronunciation Fundamentals: Evidence-based Perspectives for L2 Teaching and Research. Amsterdam: John Benjamins Publishing Company.

Gamboa, R., Chaves, L. Vásquez, L. M., \& Gapper, S. E. (August 2019). Dilemmatic Conversations on the Teaching of Pronunciation. Round table conducted at the VI Congreso Internacional de Lingüística Aplicada, Universidad Nacional de Costa Rica, Heredia.

Gilbert, J. B. (2008). Chapter 2: The Prosody Pyramid. In Teaching Pronunciation: Using the Prosody Pyramid (pp. 10-20). New York: Cambridge University Press.

Gray, B. \& Egbert, J. (2019). Register and register variation. Register Studies, 1(1), 1-9. https://doi.org/10.1075/ rs.oooo1.edi

Jarosz, A. (2019). English Pronunciation in L2 Instruction. Second Language Learning and Teaching. doi:10.1007/978-3-030-13892-9

Kralova, Z., Skorvagova, E., Tirpakova, A. \& Markechova, D. Reducing student teachers' foreign language pronunciation anxiety through psycho-social training, System, 65, 49-6o. https://doi. org/10.1016/j.system.2017.01.001
Murat, H. (2006). Current Perspectives on Pronunciation Learning and Teaching. Journal of Language and Linguistic Studies, 1, 2, 101-110.

Murphy, J. (Ed.). (2017). Teaching the Pronunciation of English. doi:10.3998/mpub.8307407

Orion, G. F. (1997). Pronouncing American English: Sounds, Stress, and Intonation. Boston: Heinle and Heinle Pub.

Saito, K. (in press) Advanced Segmental and Suprasegmental Acquisition. In P. Malovrh \& A. Benati (Eds.). The Handbook of Advanced Proficiency in Second Language Acquisition. Wiley Blackwell.

Sevilla, H. (August, 2019). Pronunciation Fluency and Accuracy in ELT: A Sociopragmatic Perspective. Paper presented at the VI Congreso Internacional de Lingüística Aplicada, Universidad Nacional de Costa Rica, Heredia.

Tudor, I. (2001). The Dynamics of the Language Classroom. Cambridge: Cambridge University Press.

Vásquez, L. M. (2020). Introduction to English Pronunciation. Universidad de Costa Rica, Sede de Occidente [unpublished manuscript].

Yoshida, M. (2014). Chapter 11: Intonation. In Understanding and Teaching the Pronunciation of English (pp. 123-131). Irvine: UC Irvine

Zoghbor, W. S. (2018). Teaching English pronunciation to multi-dialect first language learners: The revival of the Lingua Franca Core (LFC), System, 78, 1-14. https://doi.org/10.1016/j.system.2018.06.008 
Appendices

Below are some useful websites which can be used as supplementary materials to teach suprasegmentals from a register-based perspective:

1 https://tophonetics.com/ (good for phonetic transcriptions)

2. https://www.youtube.com/user/TheInfographicsShow (YouTube Channel featuring short, fun, interactive videos about a wide array of topics)

3. http://www2.nkfust.edu.tw/ emchen/Pron/rhythm. htm (ideas for practicing rhythm, pausing and thought groups)

4. http://iteslj.org/Techniques/Cohen-Suprasegmentals. html (good for raising students' awareness on suprasegmentals and the concept of reduction)

5. https://pronunciationcoach.blog/2012/12/28/limericksand-sentence-stress/ (activities to practice sentence stress and limericks) 